\begin{tabular}{cc}
\hline EJEM & $\begin{array}{c}\text { ECONOMIC JOURNAL OF } \\
\text { EMERGING MARKETS } \\
\text { Evon. J. Emerg. Mark. }\end{array}$ \\
\hline
\end{tabular}

\title{
The impact of health status and smoking behaviour on Indonesian labor wage
}

\author{
Heni Wahyuni ${ }^{1}$ \\ ${ }^{1}$ Faculty of Economics and Business, Universitas Gadjah Mada, Yogyakarta, Indonesia. \\ e-mail: hwahyuni@ugm.ac.id.
}

Article Info

\section{Article history:}

Received : 15 October 2015

Accepted : 15 March 2016

Published: 1 April 2016

Keywords:

health status, smoking behaviour, wage, two-step Heckman correction

JEL Classification:

I150, I120, J310, C240

DOI:

10.20885/ejem.vol8.iss1.art1

\begin{abstract}
In this research, we try to estimate the relationship between health status and smoking behaviour on the labour wage in Indonesia. We investigate using Indonesian Family Life Survey (IFLS) data and two-step Heckman correction to deal with sample selection bias. We found that there is significance relationships between all socioeconomic variables and wage both for smokers and nonsmokers. The interesting thing is that the effect on wage is less for smokers than non-smokers.
\end{abstract}

\section{Abstrak}

Dalam penelitian ini, kami mengestimasi hubungan antara status kesehatan dan perilaku merokok dengan upah pekerja di Indonesia. Kami menggunakan data dari Indonesian Family Life Survey (IFLS) dan two-step Heckman correction untuk menangani bias seleksi sampel. Kami menemukan bahwa terdapat hubungan signifikan antara semua variabel sosial ekonomi dengan upah, baik untuk perokok dan non-perokok. Temuan yang menarik dari penelitian ini adalah bahwa efek pada upah lebih kecil untuk perokok dibandingkan non-perokok.

\section{Introduction}

A person's health status is affected by a combination of uncontrollable factors (such as the environment, genetics, and health services) and controllable factors (such as smoking and other unhealthy behaviours). As a form of human capital, health along with education determines the productivity and wage of an individual. This research aims to estimate the impact of health and smoking behaviours on the wage rate of Indonesian workers. Since wage rate itself may affect health, and both health and wage rate may be affected by some unobservable factors, health status may be endogenous in a wage determination model. Thus, in order to take into account the possible endogeneity problem, estimates in this research will use the two-step Heckman correction of health status and wage rate. The model will be estimated using data from the Indonesian Family Life Survey
(IFLS), which contains rich data on individual health status, wage rate, individual smoking behaviours, and other socioeconomic factors such as education and type of employment.

Human capital has long been believed to be the key factor affecting productivity and also economic growth. Traditionally, human capital is often interpreted as education level and skills. However, today the concern on individual health status as a part of human capital is growing. For example, many researches on health status show that the health of a population has a positive and significant relationship with economic growth, especially in developing countries (Bloom and Mahal, 1997; Bloom and Sachs, 1998; Bloom and Canning, 2000; Bhargava et al., 2001; Bloom, Canning and Sevilla, 2001; Rivera and Currais, 1999). The reason why health is important in determining economic growth is that health status on a mi- 
cro level, as is with education, affects productivity and labor supply. Several researches have found that a better health status increases the labor participation rate as well as wages (Currie and Madrian, 1999; Stern, 1989; Bound et al., 1999; Campolieti, 2002; Cai and Kalb, 2006).

Even though a number of researches have been done on the relationship between health status and wage rage, studies on Indonesia rarely include individual smoking behaviour data obtained from IFLS. Unhealthy behaviours such as smoking is an important factor to include for the context of Indonesia since household expenditure on cigarettes and tobacco is substantial, even larger than spending on education and health. Badan Pusat Statistik (Central Statistics Agency) data shows that in 2014 average monthly expenditure per capita was 6.3 per cent for tobacco and betel, 9.1 percent for fish, meat, eggs and dairy products put together, 3.9 percent for education, and 3.2 percent for health (BPS, 2015). Regarding to the important of smoking behaviour in the analysis of wage rate, therefore, the paper tries to include this factor in the analysis and fill the gap of the existing literature.

The literature on the effect of health on the labor market is extensive and has been developing for a long time. Labor market performance is not only measured by wages but also with income. However, this research will focus on the relationship between health status and wage rate, since wages are a better measure for productivity compared to income. Hence, the literature review will pay more attention on papers concerning wage rate and health status.

The first study on the relationship between wage and health status was conducted by Grossman and Benham (1974). They used simultaneous equations with wage rate (log form), weekly employment (in yearly data), and health variables in an econometric model taking into account the endogeneity of health. The two-stage method was used to estimate the model with white males over 18 as the sample. Their research found that the variable derived illhealth has a significant negative relationship with wage rate, and wage rate has a positive effect on ill-health; the effect of wage on health is significant if individuals above 64 are included, however it is insignificant if they are excluded.

Lee (1982) used data from the National Longitudinal Survey of Men 45-49, Survey 1996 to estimate a simultaneous equation model of health and wage, with two discrete indicators for unobserved health capital. Lee found that latent health has a significant positive relationship with hourly wage (log form). Nonetheless, unlike Grossman and Benham (1974), Lee (1982) found wage rate to have a significant positive relationship with health, which substantially controlled the reverse causality of wage on health and reduced the impact of health on wage.

Haveman et al. (1994) estimated a simultaneous equation model consisting of hourly wage (in yearly data), total working hours (in yearly data) and health status using the Michigan Panel Study of Income Dynamics (PSID). Even though this research included total working hours, it excluded wage rate from the model. As a result, the reverse causality of wage rate on health was not tested. Moreover, they used the previous year's health status as a variable affecting wages. The model was estimated using a sample consisting of white males aged between 24 and 65 with GMM estimation. The research found that lagged ill-health significantly decreases wages and the effects are larger when endogeneity of health is taken into account. Cai (2007), who also used simultaneous equation to address endogeneity, found that using data from Household, Income, and Labour Dynamics in Australia (HILDA), there exists a significant positive relationship between health status and male wage rate in Australia. This significant relationship is found when endogeneity and measurement error 
of health status is taken into account. The reverse causality of wage affecting health status was not found, however the research discovered that endogeneity in health is attributed to unobservable factors. Strauss and Thomas (1998) gave a general explanation on the mechanism, concept, definition, and measurement of health in the context of how it affects wages. Strauss and Thomas (1998) explain the mechanism of treating the endogeneity problem of health status caused by unobservable factors.

Smoking behaviour is included in this study since this variable is suspected to have a strong effect towards health status and wage. Several researches identify smoking as the main cause for a number of illnesses such as heart disease, stroke, cancer, and lung disease (Doll et al, 1986; Mattsom et al, 1987). Estimates done by Peto et al. (1992) state that during the 1990s tobacco consumption account for 30 percent of all early deaths among the population aged between 35 and 69. Half of smokers who take up the behaviour in their teens are predicted to die of tobacco related illness when they reach middle age. Cancer develops in the 30s if a person starts smoking in age of $15-20$ (Peto et al, 1994; Holman et al, 1998). Manning et al. (1991) estimated that smoking decreases the life expectancy of a 20 -year-old by about 4.3 years or 7 minutes per cigarette.

Workers who smoke are suspected to have lower work productivity or higher medical expenses (or both) compared to those who do not. The average smoker is also suspected to have a lower health status and tend to miss work more often due to illness related to smoking. Bush and Wooden (1995), using data from the Australian National Health Survey 1989/1990, found that smoking has a significant impact on work absence. The probability of a male smoker to not show up to work is estimated to be 66 percent higher compared to male workers who do not smoke. Ryan et al. (1992) studied employee absence in Telecom Austral- ia in the period of 1991-1992 and found that smoking-related absence had cost the company AUD 16.5 million. Furthermore, since the 1980s many studies have looked at the impact of smoking towards non-smokers, or otherwise known as passive smoking. Several studies such as Hill (1986), Borland (1992), and Mullins et al. (1994) show that passive smoking strongly affects health, and the awareness is growing.

Levine et al. (1997) estimated the effect of smoking on wage using data from the National Longitudinal Survey of Youth. They used several methods to control for differences in individual characteristics that may be connected to smoking and health, including individual characteristics that are unobserved and constant over time and those that are unobserved and constant among family. The estimates using these several alternatives led to the conclusion that smoking decreases wage by about 4 to 8 percent. On the other hand, Lye and Hirschberg (2000) estimated the relationship between smoking, alcohol consumption, and wage using data from the 1995 Australian National Health Survey. Their research support previous findings that health status influences productivity through wage.

In Indonesia, the high prevalence of smoking contributes to early deaths, especially among males. This leads to lower life expectancy of men, increase in medical expense, and lower productivity. World Health Organization estimated that in 2010, 12.7 percent of all deaths in Indonesia was due to tobacco-related diseases. Fifty percent of passive smokers die due to tobacco-related illness (Jha et al., 2006) and the cost of treating smoking-related illness for 3 major diseases in Indonesia reach $\mathrm{Rp} 39.5$ trillion per year, or equivalent to 0,74 percent of Gross Domestic Product and 29.83 percent of total expenditure on health (Nugrahani et al., 2013).

Based on the findings of many researches and studies on the relationship between health status, smoking behaviour, and wage in many developed countries, research 
in a developing country context becomes extremely important considering not many are yet available, especially for Indonesia.

\section{Methods}

\section{Data}

The data for this research are from the Indonesian Family Life Survey (IFLS). The surveys were conducted by the RAND Corporation, together with three Indonesian institutions, the University of Indonesia, Universitas Gadjah Mada, and Survey METRE.The IFLS is a large-scale national panel/longitudinal survey that provide extensive data at three levels (individual, household, and community). It includes the characteristics of communities (e.g., health and education facilities) where the individuals and households reside. The IFLS data representing 83 percent of the population: four provinces on Sumatra (North Sumatra, West Sumatra, South Sumatra, and Lampung), all provinces in Java (DKI Jakarta, West Java, Central Java, DI Yogyakarta, and East Java), and four provinces within the remaining main island groups (Bali, West Nusa Tenggara, South Kalimantan, and South Sulawesi).

Data from IFLS that used in this study give information relating to health status (using both subjective and objective measurement), wage rate, and other socioeconomic and demographic variables such as education level, age, type of main employment, work experience, total working hours in a week, marital status, smoking behaviour, and urban or rural residency. This research will use panel data obtained from IFLS2 (1997) and IFLS3 (2000) and for individual level.

\section{Econometric model}

The model that will be used is a modified human capital health model where an individual's wage may be influenced by education level, type of employment, working experience, marital status, and several measures of health status and behaviours related to smoking.

Concerning the possibility of endogeneity in smoking behaviour, the two-step Heckman correction will be used to treat for sample selection bias. This method involves a first stage probit equation estimate that explains the difference between smokers and non-smokers:

$\operatorname{Smosd}_{i j}=Z_{i j} \theta+v_{i j}=\pi_{i j}+v_{i j}$

Where $\operatorname{Smos} d 1_{i j}=1$ means that the individual is a smoker, and $\operatorname{Smos} d 1_{i j}=0$ means that the individual is a non-smoker. $Z_{i j}$ is a list of variables that explain an individual's decision to smoke, which are marital status, gender, education, age, and region; and $v_{i j}$ is a normally distributed error term. From probit model estimation, the density function and cumulative density function of a standard normally distributed variable, $\phi(\pi)$ and $\Phi(\pi)$, are able to be calculated. The next step is to calculate Heckman's correction terms (or invers Mills ratio) as follows

$$
\begin{aligned}
& I M R^{\text {smoke }}=\phi(\pi) / \Phi(\pi) \\
& \text { and } I M R^{\text {nonsmoke }}=\phi(\pi) /\{1-\Phi(\pi)\}
\end{aligned}
$$

from the density function and distribution function.

In the second step, the following wage equation is estimated by including the IMR (invers Mills ratio) separately for smokers and non-smokers:

$$
W_{i t}^{j}=X_{i t}^{j} \alpha+Z_{i}^{j} \beta+\lambda I M R_{i t}^{j}+u_{i t}
$$

where $i$ indicates the individual being observed, $t$ is the time period, and $j$ is the individual's choice of whether to smoke or not (smoker or non-smoker). $W_{i t}$ is the natural $\log$ of average weekly wage, $X_{i t}$ is a vector of health and socioeconomic variables such as health, education, type of employment, working experience, marital 
status, and region (urban or rural). This vector is time-varying, while $Z_{i}$ is timeinvariant such as gender. $I M R_{i t}$ is the invers Mills ratio. $u_{i t}$ is the error term that satisfies the assumption of iid $N\left(0, s_{\varepsilon}^{2}\right)$.

\section{Results and Discussion}

\section{Descriptive statistics}

All data is obtained from the Indonesian Family Life Survey (IFLS), IFLS2 and IFLS3. IFLS2 is based on survey done in 1997 and IFLS3 is based on survey done in 2000. Data is at the individual level, covering adults that reside in 13 different provinces in Indonesia. The sample is taken using Stratified Random Sampling method. The following paragraphs will explain each variable in detail (see Table 1).

Wage is obtained from the question "Approximately what was your salary/wage during the last month?". The number is then divided by four to obtain average weekly wage. Only individuals above 15 years of age are included. The average wage is $\mathrm{Rp}$ $73,956.92$, while the minimum and maximum value are $\mathrm{Rp} \mathrm{88,323.93} \mathrm{and} \mathrm{Rp}$ $1,625,000$ respectively.

Using a sample of 5463 individuals, the average total working hour per week is 44.92 hours, with the maximum value being 100 hours per week. Data for this variable is obtained from the question "Normally, what is the aproximate total number of hours you work per week?". The average working hour in the sample is quite high, which is that each individual worked an average of between 8 to 9 hours per day. The average work experience of individuals that are used in the sample is also high at 21 years. Work experience variable is obtained from the survey by subtracting the individual's birth year from the starting year of their first job. The average length of schooling was 7.56 years with a maximum of 24 years. This may imply that all individuals in the sample have completed at least primary education, which is normally completed in 6 years. The average age is 31 years with a minimum value of 15 years and a maximum value of 94 years. This is consistent with the definition of "adult individuals" used in the sample.

Body Mass Index (BMI) represents health measurement. It is calculated by dividing individual bodyweight in kilograms by height in squared meters. The average $\mathrm{BMI}$ is 21.64. BMI is generally divided into four categories; fewer than 18.5 is low, 18.5 to 25 is normal, 25 up to 30 is above normal, and above 30 means that the individual is obese.

This study uses dummy variables for marital status, (married and unmarried), gender (male and female), job type (public/government or private sector), and region (urban or rural). Smoking behaviour is also a dummy variable divided into those who have and have never smoked. This variable is taken from the question "Have you had the behaviour of chewing tobacco,...?".

Table 1: Descriptive Statistics of Sample

Observation: 5463 individuals

\begin{tabular}{lrrrr}
\hline \multicolumn{1}{c}{ Variable } & \multicolumn{1}{c}{ Mean } & $\begin{array}{c}\text { Standard } \\
\text { Deviation }\end{array}$ & $\begin{array}{c}\text { Minimum } \\
\text { Value }\end{array}$ & \multicolumn{1}{c}{$\begin{array}{c}\text { Maximum } \\
\text { Value }\end{array}$} \\
\hline Average weekly wage & $73,956.92$ (rupiah) & $88,323.93$ & 500 (rupiah) & 1.625 .000 (rupiah) \\
Average weekly work- & 44.92 (hours) & 16.39075 & 0 & 100 (hours) \\
ing hours & & & & \\
Working experience & 21.17 (years) & 6.567552 & 0 & 92 (years) \\
Length of schooling & 7.56 (years) & 4.563474 & 0 & 24 (years) \\
Age & 31.67 (years) & 10.96046 & 15 (years) & 94 (years) \\
Body Mass Index (BMI) & 21.64 & 3.332175 & 13,28 & 43,47 \\
\hline
\end{tabular}

Source: IFLS2 and IFLS3 


\section{Estimation results}

The estimation is done in two steps. The first step is estimating the probit model (equation 1) to obtain the density function and the distribution function, which are then used to calculate Heckman 's correction model (inverse Mills ratio). The second step, after calculating the inverse Mills ratio (IMR), is to estimate the wage equation (equation 3 ) that includes the IMR variable. Wage equation estimation is done separately between IMR of individuals who smoke and IMR of individuals who do not smoke to see the impact of each of the explanatory variables, namely health status and socioeconomic variables, on wage.

In Table 2, it is shown that marital status was not significant. Hence the IMR is calculated using the estimation results of the probit equation in table 3 . Based on the IMR, the following tables (Table 4 and Table 5) show the results from the wage equation estimation.

Wage equation estimation results indicate that the explanatory variables in the model have a significant relationship with wage, except for bmil and bmi4. Bmi variables are divided into four categories, namely bmi1 for low, bmi2 for normal, bmi3 for high, and bmi4 for obese. All relationships have the expected sign.
Average weekly working hours shows a significant positive correlation with wages at the 1 percent level for both smokers and non-smokers. This means that an increase in average weekly working hour will increase average weekly wage for Indonesian workers. For both smokers and nonsmokers, a 1-hour increase in weekly working hour will increase wage by about 1.1 percent, and the actual figure is smaller for smokers. Likewise, work experience is also positively and significantly correlated with wage, but at a decreasing rate (negative sign for workexpsq), as explained in the literature. It is also similar with age, which is positively and significantly correlated with wage but at a decreasing rate. This means that as age and work experience increase, so does wages. However, after reaching a certain age (elderly), labor productivity decreases and consequently wage decreases too. This is consistent with what is stated in Grossman's health production theory (Grossman, 1972).

Individuals who work in the government/public sector have higher wages compared to individuals who work in the private sector. For both smokers and nonsmokers, the difference according to the estimate above is about 50 percent. This is possibly because individuals working in the government sector have a steadier stream of income.

Table 2: Probit Estimation Results Including All Explanatory Variables

Dependent variable: Smoking behaviour

\begin{tabular}{lrr}
\hline \multicolumn{1}{c}{ Variable } & Coefficient & \multicolumn{1}{c}{ Standard Error } \\
\hline Constant & $-1.942527^{* *}$ & 0.0736301 \\
Marital status (married) & -0.0148047 & 0.0256258 \\
Gender (gender) & $2.305837^{* *}$ & 0.0225515 \\
Length of education (educyears) & $-0.021772^{* *}$ & 0.0020582 \\
Age (age) & $0.0117341^{* *}$ & 0.0038189 \\
Age (agesq) & $0.000093^{*}$ & 0.0000429 \\
Region (urban) $_{\text {Prob }>\text { chi2 }}$ & $-0.1667096^{* *}$ & 0.0192959 \\
Pseudo R2 & & 0.0000 \\
Log likelihood & & 0.4063 \\
Sourc: & & -11777.269 \\
\hline
\end{tabular}

Source: IFLS2 and IFLS3

*significant at 5 percent level; **significant at 1 percent level 
Table 3: Probit Estimation Results Excluding Marital Status

Dependent Variable: Smoking behaviour

\begin{tabular}{lrr}
\hline \multicolumn{1}{c}{ Variable } & Coefficient & Standard Error \\
\hline Constant & $-1.926525^{* *}$ & 0.0682099 \\
Gender (gender) & $2.303614^{* *}$ & 0.0222044 \\
Length of education (educyears) & $-0.0217674^{* *}$ & 0.002058 \\
Age (age) & $0.0105149^{* *}$ & 0.0031847 \\
Age (agesq) & $0.0001056^{* *}$ & 0.000037 \\
Region (urban) & $-0.165633^{* *}$ & 0.0192049 \\
\hline Prob > chi2 & & 0.0000 \\
Pseudo R2 & & 0.4063 \\
Log likelihood & & -11777.436 \\
\hline
\end{tabular}

Source: IFLS2 and IFLS 3

**significant at 1 percent level

As for individuals who are married, they have a wage rate of approximately 10.6 per cent higher compared with individuals who are not married, for both smokers and non-smokers. A possible cause may be that companies tend to provide family benefits for employees that have spouses. This relationship is in accordance with previous studies, namely Gray (1997), Loh (1996), and Breush and Gray (2004).
A higher level of education increases an individual's wage. This is indicated by the positive and significant relationship between length of education and wage at the 1 percent level. Increasing one's level of education by 1 year will increase wage by 6.6 percent up to 6.8 percent. That is, the higher the person's level of education the higher the level of wage (Grossman and Kaestner, 1997).

Table 4: Wage Equation Estimate for Smokers

Dependent Variable: lnweeklywage

\begin{tabular}{|c|c|c|}
\hline Variable & Coefficient & Standard Error \\
\hline Constant & $7.221001 * *$ & 0.42776 \\
\hline Total weekly working hours (weeklyworkhours) & $0.0109633 * *$ & 0.0006714 \\
\hline Working experience (workexp) & $0.0145768 * *$ & 0.0055948 \\
\hline Working experience $^{2}$ (workexpsq) & $-0.0003381 * *$ & 0.0000944 \\
\hline Job type (jobcat) & $0.5224845^{* *}$ & 0.0296246 \\
\hline Marital status (married) & $0.1062542 * *$ & 0.0300085 \\
\hline Gender (gender) & $0.3834483 * *$ & 0.0267404 \\
\hline Length of education (educyears) & $0.0667467 * *$ & 0.0024163 \\
\hline Age (age) & $0.0701068 * *$ & 0.0063797 \\
\hline $\operatorname{Age}^{2}$ (agesq) & $-0.000916 * *$ & 0.0000815 \\
\hline Region (urban) & $0.2642106^{* *}$ & 0.0234316 \\
\hline BMI1 & 0.0276068 & 0.0231435 \\
\hline BMI2 & $0.0325123 * *$ & 0.0062618 \\
\hline BMI3 & $0.0282478^{*}$ & 0.0137998 \\
\hline BMI4 & -0.0345405 & 0.025312 \\
\hline Smoker IMR (IMRsmoker) & $0.0874781 *$ & 0.0427752 \\
\hline Total observations & & 5463 \\
\hline R-squared & & 0.3529 \\
\hline Adj R-squared & & 0.3511 \\
\hline $\mathrm{F}(15,5447)$ & & 198.03 \\
\hline
\end{tabular}

Source: IFLS2 and IFLS 3

**significant at 1 percent level; * signifikan pada tingkat 5 persen 
Table 5: Wage Equation Estimate for Non-Smokers

Dependent Variable: lnweeklywage

\begin{tabular}{|c|c|c|}
\hline Variable & Coefficient & Standard Error \\
\hline Constant & $7.367472 * *$ & 0.4392634 \\
\hline Total weekly working hours (weeklyworkhours) & $0.0109782 * *$ & 0.0006715 \\
\hline Working experience (workexp) & $0.0145873 * *$ & 0.0056009 \\
\hline Working experience ${ }^{2}$ (workexpsq) & $-0.0003396^{* *}$ & 0.0000946 \\
\hline Job type (jobcat) & $0.5217888 * *$ & 0.0296272 \\
\hline Marital status (married) & $0.106985^{* *}$ & 0.0300134 \\
\hline Gender (gender) & $0.2798136^{* *}$ & 0.0843782 \\
\hline Length of education (educyears) & $0.0676868 * *$ & 0.0024565 \\
\hline Age (age) & $0.0694053 * *$ & 0.0064141 \\
\hline $\mathrm{Age}^{2}($ agesq) & $-0.0009162 * *$ & 0.0000816 \\
\hline Region (urban) & $0.2717775^{* *}$ & 0.0235624 \\
\hline BMI1 & 0.0279983 & 0.023145 \\
\hline BMI2 & $0.0322523 * *$ & 0.0062598 \\
\hline BMI3 & $0.0281767 *$ & 0.0138036 \\
\hline BMI4 & -0.0341708 & 0.0253161 \\
\hline Non-Smoker IMR (IMRnonsmoker) & -0.065679 & 0.0410964 \\
\hline Total observations & & 5463 \\
\hline R-squared & & 0.3527 \\
\hline Adj R-squared & & 0.3509 \\
\hline $\mathrm{F}(15,5447)$ & & 197.87 \\
\hline
\end{tabular}

Source: IFLS2 and IFLS 3

**significant at 1 percent level; * signifikan pada tingkat 5 persen

If we look at the differences in wage levels by region, then individuals who work in urban areas have a higher wage rate of about 27 percent compared to individuals who work in rural areas, smokers and nonsmokers alike. The explanation for this finding is that generally jobs in urban areas are of a skilled nature, thus wages are higher compared to unskilled jobs that are normally found in rural areas.

The last explanation is for the health status variables. These are the variables that are of particular concern in this study. Health status is represented by body mass index, which is one measure of anthropometrics. Body Mass Index is calculated by dividing weight in kilograms by the person's height in squared meters. Here, BMI is divided into 4 categories. Good health status is indicated by bmi2, which has a value between 18.5 and 25 and is considered normal. A BMI under this value is taken as poor health, however so is bmi4 which indicates obesity. Based on the esti- mates above, it is found that bmi2 (normal) and bmi3 (above normal) is significantly positively related to wage levels. This shows that good health status can improve productivity and ultimately lead to increased wage. As for bmi4, which are individuals with obesity, the relationship with wage is negative. Poor health will reduce productivity and consequently lower wage. However, the results find no significant association.

\section{Conclusion}

Using data from the Indonesian Family Life Survey, this study tried to look at the relationship between the level of wages in Indonesia with health status, socioeconomic variables, and smoking behavior by modifying the standard model of human capital of health where individual characteristics may affect earnings through the differences in the level of education, type of employment, work experience, marital status, and 
several measures of health and behaviours relating to smoking.

With regard to problems with endogeneity in smoking choice, the two-step Heckman correction is used to overcome the problem of sample selection bias. This involves a first stage probit estimation equation that shows the differences between individual smokers and nonsmokers, which is then followed by estimation of wage equation.

Based on the estimates, health status and all socioeconomic variables affect wages significantly and with the expected signs, for both smokers and nonsmokers. Results of this study confirm the results of previous studies. For example, health status variables are significantly and positively correlated with wage.

The second important thing found in this study is that the positive impact of health status variables and other socioeconomic factors on wages was lower for smokers than nonsmokers. That is, wage increases are higher for individuals who are not smokers compared to those who are smokers. It is confirmed by health status that non-smokers have better productivity than smokers. This is a note for individuals, the society and policy makers to be more concerned about health and smoking behavior, for example by promoting reduction in cigarette consumption in Indonesia.

However, we need to realize that wages are only one aspect of economic prosperity that can be affected by health status. Impact on total economic welfare may be higher if labor force participation is also in fact influenced by health status and economic well-being derived from a combination of wages and labor supply. Thus, research on the relationship between health status and labor supply is an appealing future opportunity. Furthermore, the problems of endogeneity and measurement error are a challenge on its own in the issue of health status and wages. Therefore, research can be developed by using better methodology, for example by using panel method and including instrument variables to better control the problem of unobserved heterogeneity. Another dimension is to test the impact of health status on the variance of wages or income, where a large variance in wages is associated with great uncertainty that has a negative impact on the welfare of individuals.

\section{References}

Bloom, D.E., and Canning, D. (2000), "The Health and Wealth of Nations, Science," 287(5456), 1207-1209.

Badan Pusat Statistik, 2015, Monthly Average Spending per Capita in Urban and Rural Areas by Goods Type [data file], http://bps.go.id/linkTabelStatis/vie w/id/942, accessed $27^{\text {th }}$ January 2016, 9.00 west Indonesian time.

Bloom, D.E., and Mahal, A. (1997), "Does the AIDS Epidemic Threaten Economic Growth in Africa," Journal of Econometrics, 77, 105-124.

Bloom, D.E., and Sachs, J.D. (1998), "Geography, Demography, and Economic Growth in Africa," Brookings Papers on Economic Activities, 2, 207-295.

Bloom, D.E., Canning, D. and Sevilla, J. (2001), "Effect of Health on Economic Growth: Theory and Evidence," NBER Working Paper No. 8587, November.

Borland, R., Chapman, S. Owen, N. and Hill, D. (1990), "Effects of workplace bans on cigarette consumption," American Journal of Public Health, 80, 178-180.

Bound, J., M. Schoenbaum, T.R. Stinebrickner, and T. Waidmann (1999), "The Dynamic Effects of Health on the Labor Force Transitions of Old- 
er Workers," Labour Economics, 6, 179-202.

Breusch, T. and E. Gray (2004) "Does Marriage Improve the Wages of Men and Women in Australia?", paper presented at $12^{\text {th }}$ Biennial Conference of the Australian Population Association, September, Canberra, Australia.

Bush R., and Wooden, M. (1995), "Smoking and absence from work: Australian evidence," Social Sciences and Medicine, 41, 437-46.

Cai, L. (2007), "Effect of Health on Wages of Australia Men," Melbourne Institute Working Paper Series No.2/07, http://www.melbourneinstitute.com/ wp/wp2007n02.pdf, accessed 18 June 2009, 13.00 west Indonesian time.

Cai, L., and Kalb G. (2006), "Health Status and Labour Force Participation: Evidence from Australia," Health Economics, 15, 241-261.

Campolieti, M. (2002), "Disability and the Labor Force Participation of Older Men in Canada," Labour Economics, 9, 405-432.

Curry, S.J, Grothaus, L.C. McAfee, T. and Pabiniak, C. (1998), "User and Cost Effectiveness of Smoking-Cessation Services under Four Insurance Plans in a Health Maintenance Organization," The New England Journal of Medical, 339(9), 673-679.

Currie, J., and Madrian, B.C. (1999), "Health, Health Insurance and the Labor Market," in O. Ashenfelter and D. Card (eds.), Handbook of Labor Economics Vol. 3, 3310-3415.

Doll, R. (1986), "Tobacco: an overview of health effects," IARC Scientific Publications, 74, 11-22.
Evans, W.N, Farrelly, M.C. and Montgomery, E. (1999), "Do Workplace Smoking Bans Reduce Smoking," American Economic Review, Paper and Proceedings, 89(9), 729-747.

Gambin, L. (2004), "Gender differences in the effect of health on wages in Britain," ECuity III Working Paper No. 20.

Gray, J. (1997), “The Fall in Men's Returns to Marriage: Declining Productivity Effect or Changing Selection," Journal of Human Resources, 32 (3), 485-504.

Grossman, M., and Benham, L. (1974), "Health, Hours and Wages," in Perlman, M (eds.), The Economics of Health and Medical Care, 205233, Macmillan, London.

Grossman, M., and Kaestner, R. (1997), "Effects of Education on Health," in J.R. Brehman and N. Stacey (eds.), The Social Benefits of Education, 69-122, University of Michigan Press, Michigan.

Gruber, J. (2001), "Youth Smoking in the 1990's: Why Did It Rise and What Are the Long-run Implications?," American Economic Review, Papers and Proceedings, 91(2), 8590.

Hanaoka, C., "Smoking Participation among Japanese Men and Women," PIE/CIS Discussion Paper No.411/09, Center for Intergenerational Studies, Institute of Economic Research, Hitotsubashi University.

Haveman, R., Wolfe, B. Kreider, B. and Stone M. (1994), "Market Work, Wages, and Men's Health," Journal of Health Economics, 13, 163-182.

Hill, D., (1986), "Public Opinion about Smoking in Restaurants and at Work," Medical Journal of Australia, 145, 657-658. 
Holman, C., B. Armstrong, L. Arias, C. Martin, et al. (1988), The quantification of drug caused morbidity and mortality in Australia, Commonwealth Department of Community Services and Health, Canberra.

Jackle, R, and O. Himmler. "Health and Wages - Panel Data Estimates Considering Selection and Endogeneity," Munich Personal RePEc Archive. MPRA Paper No. 11578/08, http://mpra.ub.unimuenchen.de/11578/, accessed 18 June 2009, 13.30 west Indonesian time.

Jha, P., F.J Chaloupka, P.C Gupta, R. Peck, et al., 2006, Tobacco addiction. Disease Control Priorities in Developing Countries, $2^{\text {nd }}$ Edition, 869-886, Oxford University Press, New York.

Lee, L. (1982), "Health and Wages: A Simultaneous Equation Model with Multiple Discrete Indicators," International Economic Review, 23, 199221.

Levine, P. B., Gustafson, T.A. and Velenchik A.D. (1997), "More bad news for smokers? The effects of cigarette smoking on wages," Industrial and Labor Relations Review, 50, 493-509.

Loh, E. (1996), "Productivity Differences and the Marriage Wage Premium for White Males," Journal of Human Resources, 31, 566-589.

Lye, J.N, and Hirschberg, J. (2004), “Alcohol Consumption, Smoking and Wages," Applied Economics, Taylor and Francis Journals, 36(16),18071817 ,

http://www.economics.unimelb.edu. au/downloads/wpapers-00-

01/764.pdf, accessed 18 June 2009, 13.50 west Indonesian time.
Manning, W. G., Keeler, E. B. and Newhouse, J.P. (1991), The Costs of Poor Health Behaviours. Harvard University Press, Cambridge.

Mattsom, M. E., Pollack, E. S. and Cullen J. W. (1987), "What are the odds that smoking will kill you?" American Journal of Public Health, 77, 425-431.

Mullins, R., and Borland R. (1994), "How bothered are people by environmental smoke?" Medical Journal of Australia, 160 (9), 585-6.

Nugrahani, Y, Radjiman, D. S. Adawiyah, E.and Tabrany H. (2013), "The Impact of Smoking to Annual Economic Consequences in Indonesia: Cost of Treatment of Tobacco Related Diseases in Indonesia," paper presented at $9^{\text {th }}$ iHEA World Congress on Health Economics, $7^{\text {th }}-$ $10^{\text {th }}$ July 2013, Sydney.

Peto, R., Lopez, A. D. Boreham, J. Thun, M. and Heath Jr. C. (1992), "Mortality from tobacco in developed countries: indirect estimation from national vital statistics," Lancet, 339, 1268-1278.

Peto, R., Lopez, A. D. Boreham, J. Thun, M. and Heath Jr. C. (1994), "Mortality from smoking in developed countries 1950-2000: indirect estimation from national vital statistics," Oxford University Press, Oxford.

RAND Corporation (1997), Indonesian Family Life Survey [data file], http://www.rand.org/labor/FLS/IFL

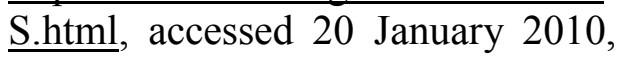
10.00 west Indonesian time.

RAND Corporation (2000), Indonesian Family Life Survey [data file], http://www.rand.org/labor/FLS/IFL

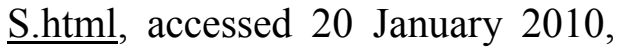
10.00 west Indonesian time. 
Rivera, B., and Currais L. (1999), "Economic Growth and Health: Direct Impact or Reverse Causation?" Applied Economics Letters, 6, 761764.

Ryan, J., Zwerling, C. and Orav O. J. (1992), "Occupational Risks associated with cigarette smoking: a prospective study," American Journal of Public Health, 82, 29-32.

Shaw, W.D, Yen, S.T. and Yuan Y. (2009), "Self-Assessed Health and Cigarette Smoking in China," Far East and South Asia Meeting of the Econometric Society, https://editorialexpress.com/cgibin/c onfe-

rence/download.cgi?db name $=$ FEM ES09\&paper $\mathrm{id}=774$, accessed 18 June 2009, 14.10 west Indonesian time.

Stern, S. (1989), "Measuring the Effect of Disability on Labour Force Partici- pation," Journal of Human Resources, 24, 361-395.

Strauss, J., and Thomas, D. (1998), "Health, Nutrition, and Economic Development," Journal of Economic Literature, XXXVI, 766-817

Witoelar, F. Rukumnuaykit P. and Strauss, J. (2005), "Smoking Behaviour among Youth in a Developing Country: The Case of Indonesia," Population Association of America 2006 Annual Meeting Program, http://paa2006.princeton.edu/downl oad.aspx? submissionId=60756, accessed 18 June 2009, 14.30 west Indonesian time.

World Health Organization (2012), Global Adult Tobacco Survey: Indonesia Report 2011 , http://www.who.int/tobacco/surveill ance/survey/gats/indonesia_report.p df, accessed 21 January 2016. 